\title{
Article \\ The Brown Marmorated Stink Bug (Halyomorpha halys Stål.) Influences Pungent and Non-Pungent Capsicum Cultivars' Pre- and Post-Harvest Quality
}

\author{
Tilen Zamljen *(D), Robert Veberic $(\mathbb{D}$, Metka Hudina $(\mathbb{D})$ and Ana Slatnar \\ Department of Agronomy, Biotechnical Faculty, University of Ljubljana, Jamnikarjeva ulica 101, \\ SI-1000 Ljubljana, Slovenia; robert.veberic@bf.uni-lj.si (R.V.); metka.hudina@bf.uni-lj.si (M.H.); \\ ana.slatnar@bf.uni-lj.si (A.S.) \\ * Correspondence: tilen.zamljen@bf.uni-lj.si; Tel.: +386-40240201
}

check for

updates

Citation: Zamljen, T.; Veberic, R.; Hudina, M.; Slatnar, A. The Brown Marmorated Stink Bug (Halyomorpha halys Stål.) Influences Pungent and Non-Pungent Capsicum Cultivars' Pre- and Post-Harvest Quality. Agronomy 2021, 11, 2252. https:// doi.org/10.3390/agronomy11112252

Academic Editor: Stefano Bedini

Received: 23 September 2021

Accepted: 5 November 2021

Published: 8 November 2021

Publisher's Note: MDPI stays neutral with regard to jurisdictional claims in published maps and institutional affiliations.

Copyright: (c) 2021 by the authors. Licensee MDPI, Basel, Switzerland. This article is an open access article distributed under the terms and conditions of the Creative Commons Attribution (CC BY) license (https:/ / creativecommons.org/licenses/by/ $4.0 /)$.

\begin{abstract}
Halyomorpha halys is an important invasive pest that causes severe damage to fruits and vegetables. Peppers are susceptible to infestation by $H$. halys, resulting in yield losses. Plants respond to the insect infestation with a metabolic response. With this study, we attempted to determine the intensity of the metabolic response of infested peppers, how pungent and non-pungent peppers react to the infestation, and how the $H$. halys affects the post-harvest quality of both cultivars. The shelf life of the infested peppers did not change compared to the control treatments. We observed a drastic decrease in metabolite levels after storage in all three treatments in both cultivars, especially capsaicinoids, with an approximate decrease of $30 \%$ in the pericarp and $95 \%$ in the placenta of the pungent 'Eris F1'. In some cases, the accumulation of metabolites was not limited to the fruit exposed to the $H$. halys infestation, but to the entire plant. We observed a 15 -fold increase in capsaicinoid content in the infested fruits of cultivar 'Eris F1' and a 4-fold increase in the pericarp of cultivar 'Lombardo tago', which could lead to a possible further study on the defensive function of capsaicinoids and their use against $H$. halys.
\end{abstract}

Keywords: capsaicinoids; organic acid; pests; phenolics; storage

\section{Introduction}

Peppers (Capsicum sp. L.), both pungent and not pungent cultivars, are widely cultivated around the world [1]. They are cultivated for their versatile usage in the culinary industry and for their benefits to human health, with a high vitamin $C$ content, low sucrose content, and pungent cultivars for their capsaicinoid content [2,3]. There are 25 species in the genus Capsicum, of which five are widely cultivated that are susceptible to pests and diseases [4]. Although pepper pests change with the location of production (geography, climate), there are several pests of peppers, some of the more important being thrips (Thysanoptera), aphids (Aphis sp.), greenhouse whitefly (Trialeurodes vaporariorum L.), and tobacco whitefly (Bemisa tabaci L.), which all cause severe damage to pepper plants and are a major problem for farmers across the world [5-7].

The brown marmorated stink bug (Halyomorpha halys Stål.) has recently become a major problem. With its large number of host plants, from ornamental plants to fruit and vegetable plants, it causes serious damage to agriculture in Europe and North America [8]. It causes damage to fruit such as apples, blueberries, etc., making them inedible for humans [9]. Several things have helped this pest to become so successful in spreading across the world, including climate change, lack of natural predators, and global trade [10]. The plant-host system, in our case the H. halys-pepper system, was previously studied by Mensah-Bonsu, et al. [11], which reported that the color of the peppers was not the main reason why the $H$. halys infested peppers, but it was rather a mix of chemical and visual preferences. Red bell peppers contain carotenoids, which play important roles in insects 
and are involved in providing coloration to various portions of their bodies and eggs, mating signals, vision, and diapause, as well as serve as antioxidants [11,12]. Common damage signs on sweet bell peppers are pale-yellow cloudy areas on the fruit surface associated with whitish, spongy tissue beneath the affected area $[13,14]$.

Damage to fruit caused by pests or diseases can decrease shelf life and can cause economic damage [15], which results in less food for human consumption. The post-harvest quality of peppers is optimally maintained with low temperatures and high humidity [16]. The optimal storage temperature of peppers is between $7^{\circ} \mathrm{C}$ and $10^{\circ} \mathrm{C}$, as reported by Hameed, et al. [17] and Lama, et al. [18]. Peppers can be stored for up to 28 days in a cool storage room with sufficient humidity from $90 \%$ to $95 \%$ [16]. H. halys may decrease storage time, since it pierces the fruit, causing small wounds that can lead to fungal infections [19]. A natural response of plants is to synthesize a defensive substance such as phenolics, which act as a repellent or deterrent, or are toxic to the pests [20]. Non-pungent and pungent peppers synthesize phenolic and capsaicinoid compounds, which can act as repellents for insects, affecting their reproduction cycle or interfering with feeding [21,22]. Among phenolics, flavones are one of the common defense molecules against insects [23]. To be grouped into the non-pungent group, a pepper should contain from $0 \mathrm{~g}$ to $0.045 \mathrm{~g} \mathrm{~kg}^{-1}$ fresh weight of capsaicinoids [24,25].

Here, we analyzed the damage of $H$. halys to peppers and their chemical response in terms of primary and secondary metabolites in the pericarp and placenta. We tried to answer the following questions. Do different fruit tissues react differently to biotic stress? Does $H$. halys have an effect on the post-harvest quality and shelf-life of pungent and non-pungent peppers, since the damage can be unseen by the farmers, resulting in yield loss occurring after storage? Does capsaicinoid content increase in biotic stressed pepper plants, which might indicate a potential defense function and could be further investigated in upcoming studies? Since there are only a few reports on $H$. halys damage to fruit and vegetables in terms of metabolites and no studies on their impact on the post-harvest quality of fruit and vegetables, our study fills a major void in this area of science and could clarify our view on this major and difficult-to-control pest.

\section{Materials and Methods}

\subsection{Experiment Design}

The experiment was carried out in Voklo, Slovenia $\left(46^{\circ} 12^{\prime} 53.78^{\prime \prime} \mathrm{N} ; 14^{\circ} 25^{\prime} 21.31^{\prime \prime} \mathrm{E}\right)$ at a local vegetable producer. The plants were grown from 20th of May to 15th of October 2020 by following the Integrated Production Guidelines [26]. Two cultivars were taken into consideration for this experiment. The first cultivar was the non-pungent Capsicum annuum L. 'Lombardo tago,' and the second was pungent Capsicum annuum L. 'Eris F1'. Both cultivars were grown under a high tunnel system. The average temperature and relative humidity were measured in the area of the plants and in storage. The average temperature in the environment was $18.2^{\circ} \mathrm{C}$, with $81.3 \% \pm 2.4$ relative humidity.

\subsection{Treatments}

Three treatments were established on each cultivar:

(1) control treatment (Control 1);

(2) H. halys treatment (H. halys);

(3) empty bag treatment (Control 2).

In the $H$. halys treatment, the bags contained five $H$. halys adults each. To exclude the potential impact of the bag itself, we placed empty bags on healthy plants, designating the treatment Control 2. In the Control 1 treatment, there were healthy plants that were not subjected to $H$. halys infestation. $H$. halys adult bugs were caught in an apple orchard in Bilje, Slovenia. For easier control over the bugs, insect netting bags were made (the netting density was $0.8 \mathrm{~mm} \times 0.8 \mathrm{~mm}$ ) and were sealed with a rubber string. The bugs were in the netting for one month, from 15th August to 15th September. Two to three such bags were placed on each plant and tied tightly to prevent the bugs from escaping. Each 
bag contained 12 to 15 fruits, resulting in 72 to 90 pepper fruits per treatment. They were divided into equal repetitions for metabolite analysis (five repetitions for each treatment).

\subsection{Pepper Picking}

Peppers were picked when they reached at least 95\% cultivar specific color (in both cases red), were firm to the touch, and had a shiny pericarp. At the time of picking, 'Lombardo tago' peppers were sized from 12 to $15 \mathrm{~cm}$ long and were up to $2.5 \mathrm{~cm}$ in diameter, and 'Eris F1'peppers were from 10 to $14 \mathrm{~cm}$ long and up to $1.5 \mathrm{~cm}$ in diameter.

\subsection{Storage Conditions}

Half of the picked peppers were stored in a storage room for one month to test whether $H$. halys impacts the storage life and metabolite composition of peppers. After storage, the peppers were sensorial checked (visual damage, odor) for any damage and prepared for metabolite analysis. The optimal storage temperature for peppers is between $7^{\circ} \mathrm{C}$ and $10^{\circ} \mathrm{C}$, as reported by Hameed, Malik, Khan, Imran, Umar, and Riaz [17] and Lama, Alkalai-Tuvia, Chalupowicz and Fallik [18]. In our study, the average storage temperature was $8.1{ }^{\circ} \mathrm{C}$ with a relative humidity of $97.2 \%$. The pericarp and placenta were used for metabolite analysis on the HPLC/MS system (MS/MS; LTQ XL; Thermo Scientific, Waltham, MA, USA and Vanquish; Thermo Scientific, Waltham, MA, USA).

Water loss of stored peppers was measured by weighing them before storage and after storage. With the data of the fresh mass and dry mass, we determined the percent of water loss in individual treatments.

\subsection{Extraction of Sugars and Organic Acids}

Lyophilized dried powder $(0.05 \mathrm{~g})$ was extracted with $2 \mathrm{~mL}$ of bi-distilled water at room temperature. Samples were shaken on an orbital shaker for $30 \mathrm{~min}$ and placed in a cooled centrifuge (Eppendorf, Centrifuge 5810 R, Hamburg, Germany), in which the samples were rotated at $12,000 \times g$ for $8 \mathrm{~min}$. Samples were filtered through $0.25 \mu \mathrm{m}$ cellulose filters (Chromafil A-25/25; Macherey-Nagel, Düren, Germany). The extraction procedure and the HPLC settings were based on Zamljen, et al. [27]. All data were calculated with the help of appropriate standards. The results are presented as $\mathrm{g} \mathrm{kg}^{-1}$ or $\mathrm{mg} \mathrm{kg}^{-1}$ dry weight, depending on the content of each metabolite. The pericarp and placenta were used for total sugar and organic acid analysis.

\subsection{Extraction of Phenolics and Capsaicinoids}

For each of the metabolite extractions, $0.05 \mathrm{~g}$ of dry powder was extracted with $80 \%$ methanol. Samples were then placed in a cooled ultrasonic bath $\left(0^{\circ} \mathrm{C}\right)$ for $1 \mathrm{~h}$. The samples were centrifuged at $10,000 \times g$ for 6 min and filtered through a $0.25 \mu \mathrm{m}$ polyamide filter (Chromafil AO-45/25, Macherey-Nagel, Düren, Germany).

Total phenolic contents were determined based on Singleton, et al. [28]. The total phenolic contents were presented in $\mathrm{g} \mathrm{kg}^{-1} \mathrm{GAE}$ (gallic acid equivalents). For individual phenolics and capsaicinoids, the HPLC/MS settings were based on Medic, et al. [29] and Zamljen, et al. [27], respectively. All individual phenolics and capsaicinoids were first determined by HPLC/MS based on Mikulic-Petkovsek, et al. [30] and Zamljen, Jakopič, Hudina, Veberič, and Slatnar [27]. All phenolics and capsaicinoids were calculated based on appropriate standards. Where no standard could be obtained, we calculated the data as equivalents of similar substances obtainable as standards. All luteolin glycosides and chrysoeriol 7-O-(2-apiosyl-6-acetyl) glucoside were calculated as luteolin-7-glucoside equivalents. Apigenin glycosides were calculated as apigenin-7-glucoside equivalents. Quercetin glycosides were calculated as quercetin-3-glucoside equivalents. Homocapsaicin was calculated as capsaicin and homodihydrocapsaicin as dihydrocapsaicin equivalents. The results of individual phenolics and capsaicinoids were expressed in $\mathrm{g} \mathrm{kg}^{-1}$ or $10^{-3} \mathrm{~g} \mathrm{~kg}^{-1}$ dry weight, depending on the content of each metabolite. 


\subsection{Chemicals}

Several standards were used for our study. For sugars, the standards were sucrose, glucose, and fructose (Sigma-Aldrich Chemie $\mathrm{GmbH}$, Steinheim, Germany); for organic acids, oxalic acid, citric acid, malic acid, succinic acid, quinic acid, ascorbic acid, and fumaric acid (Sigma-Aldrich Chemie $\mathrm{GmbH}$, Steinheim, Germany); for individual phenolics, 5-caffeoxlquinic acid, luteolin-7-glucoside, quercetin-3-glucoside, and apigenin7-glucoside (Sigma-Aldrich Chemie $\mathrm{GmbH}$, Steinheim, Germany); for capsaicinoids, capsaicin, dihydrocapsaicin, and nordihydrocapsaicin (Sigma-Aldrich Chemie $\mathrm{GmbH}$, Steinheim, Germany).

\subsection{Statistical Analysis}

Program R, version 2.7.1., Stanford, USA (Package Rcmdr) (Team, R.D.C., 2008) was used for statistical analysis. First, the data were checked for normality and equal variances using Levene's test. F-values, p-values, and df were placed into the footnotes of each table. The $\mathrm{df}$ were the same in each treatment and table, since the number of treatments was the same every time $(\mathrm{df}=2)$. Where significant treatment effects were found using multi-way analysis of variance (MANOVA), the post hoc Duncan test was performed, comparing all treatments to the Control 1 healthy plant treatment. The factors in the MANOVA were fruit part, storage, $H$. halys infestation, and cultivar. The cultivars were tested separately. The dependent variables were sugars, organic acids, phenolics, and capsaicinoids. In the results, we presented Wilks' $\lambda, F$ and p value. The significant level was $\alpha \leq 0.05$. In tables where no statistical differences could be observed, for an easier overview of the data, no letters were written.

\section{Results}

\subsection{Visual Appearance of Pepper Fruit and Water Loss}

Visual inspection of all three treatments' fruit did not show any visual changes. All fruit were visually marketable at both inspections, before and after $28 \mathrm{~d}$ storage (Figure 1). A noticeable smell came from the H. halys infested fruit in both inspections, before and after storage. This smell is common for $\mathrm{H}$. halys, and it derives from trans-2-octenal and trans-2-decenal aldehydes [31]. We could not visualize any marks on the fruit because the stylet bundle, with which the insect feeds, is only $45 \mu \mathrm{m}$ in diameter, which results in microscopic puncture holes [32], and the peppers were red colored making it harder to spot.

Water loss after storage was minimal in all treatments (Table 1). Regarding dry weight, the pericarp of pungent 'Eris F1'was affected significantly by $H$. halys (Wilks' $\lambda=0.002$, $\mathrm{F}=15.42, p<0.000$ ), but it was not related to the placenta (Wilks' $\lambda=0.532, \mathrm{~F}=1.42$, $p=0.325$ ) or their interaction (Wilks' $\lambda=0.635, \mathrm{~F}=0.42, p=0.104$ ). Similarly, after storage, the pericarp was affected significantly by $H$. halys (Wilks' $\lambda=0.004, \mathrm{~F}=20.31, p<0.000$ ), but it was not related to placenta (Wilks' $\lambda=0.493, \mathrm{~F}=0.52, p=0.245$ ) or their interaction (Wilks' $\lambda=0.565, \mathrm{~F}=0.99, p=0.351$ ).

The non-pungent 'Lom-bardo tago' pericarp or placenta were not affected by $H$. halys (Wilks' $\lambda=0.332, \mathrm{~F}=0.89, p=0.125$ ). Similar results were also present after storage.

The Control 1 treatment lost more water compared to the other two treatments during storage. In general, the placenta lost more water in the pungent 'Eris F1' than the pericarp. Among treatments, statistical differences were present in the pungent 'Eris F1' pericarp before and after storage, where the Control 1 treatment had approximately $3 \%$ higher contents compared to the H. halys and Control 2 treatment. Water loss is closely associated with cultivar, cell membrane ion leakage, lipoxygenase activity, and cuticular wax amount [33]. With controlled temperature, relative humidity, and, in certain cases, atmosphere, we can control most of these processes, especially respiration rate, in the fruit or vegetable, reducing water loss and thus maintaining quality [34]. 

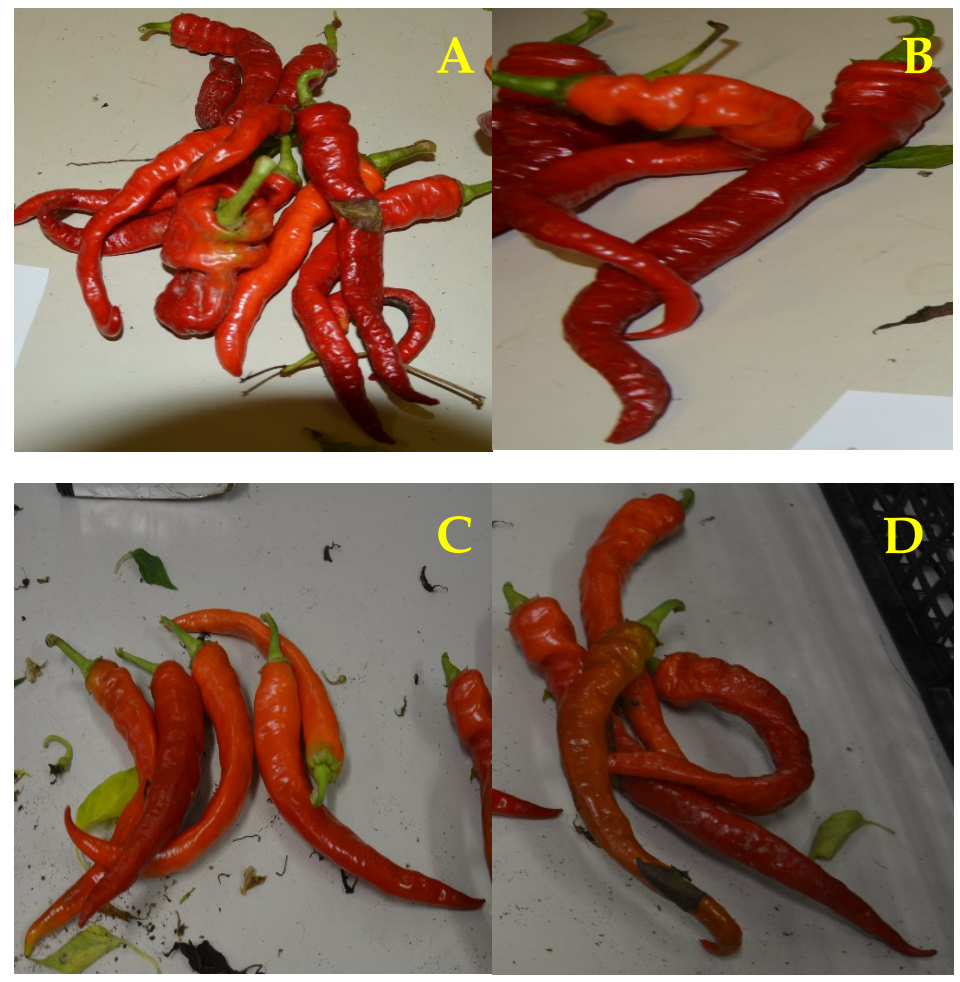

Figure 1. Non-pungent 'Lombardo tago' before (A) and after storage (B) and pungent 'Eris F1' before (C) and after storage (D).

Table 1. Average water contents (\%) before and after storage of two Capsicum cultivars (two fruit parts) infested with H. halys.

\begin{tabular}{|c|c|c|c|c|c|c|c|}
\hline & & \multicolumn{3}{|c|}{ Before Storage } & \multicolumn{3}{|c|}{ After Storage } \\
\hline & & Control & H. halys & Control 2 & Control & H. halys & Control 2 \\
\hline Pungent & Pericarp & $87.2 \pm 1.0 \mathrm{a}^{i}$ & $84.5 \pm 1.3 b$ & $84.2 \pm 1.2 b$ & $86.4 \pm 1.2 \mathrm{a}$ & $83.7 \pm 1.3 b$ & $83.8 \pm 1.2 b$ \\
\hline 'Eris F1' & Placenta & $89.4 \pm 2.1$ & $86.9 \pm 1.7$ & $88.4 \pm 1.9$ & $85.0 \pm 1.0$ & $84.8 \pm 1.1$ & $86.2 \pm 0.9$ \\
\hline Non-pungent & Pericarp & $87.9 \pm 1.7$ & $86.2 \pm 1.4$ & $86.6 \pm 1.9$ & $87.0 \pm 1.2$ & $86.0 \pm 1.2$ & $86.2 \pm 1.4$ \\
\hline 'Lombardo tago' & Placenta & $89.4 \pm 2.2$ & $87.7 \pm 2.0$ & $86.5 \pm 2.4$ & $87.4 \pm 0.9$ & $85.8 \pm 1.0$ & $85.9 \pm 1.0$ \\
\hline
\end{tabular}

$i$ a, $b$ different letters denote statistically significant differences $(\alpha \leq 0.05)$ among treatments in the same cultivar and fruit part before and after storage.

\subsection{Indiviudal and Total Sugar Contents}

Regarding individual and total sugar contents, the pericarp and placenta of pungent 'Eris F1'were affected significantly by $H$. halys (Wilks' $\lambda=0.032, \mathrm{~F}=12.42, p<0.001$ ). Similarly, after storage, the pericarp and placenta were affected significantly by $H$. halys (Wilks' $\lambda=0.009, \mathrm{~F}=13.31, p<0.001$ ).

The non-pungent 'Lom-bardo tago' pericarp and placenta were affected by $H$. halys (Wilks' $\lambda=0.032, \mathrm{~F}=8.89, p=0.005$ ). Similar results were also present after storage (Wilks' $\lambda=0.029, \mathrm{~F}=7.89, p=0.002$ ).

$H$. halys treatment increased the total sugar content in the pericarp and placenta, compared to the empty bag treatment (Control 2) in pungent cultivar 'Eris F1' (Table 2). Sucrose was not statistically impacted by the $H$. halys attack in either tissue of 'Eris F1'. In

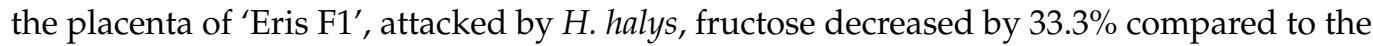
healthy Control 1 plants, but it increased by $57.5 \%$ compared to the Control 2 treatment. The H. halys-attacked fruit had $48.6 \mathrm{~g} \mathrm{~kg}^{-1}$ (Control 1) and $75.0 \mathrm{~g} \mathrm{~kg}^{-1}$ (Control 2) fewer total sugars than both control treatments in the non-pungent 'Lombardo tago' pericarp. A greater effect of $H$. halys was observed in the placenta of 'Lombardo tago', in which it decreased the total sugar contents by $33.2 \%$ compared to the Control 1 treatment. 
Table 2. Individual and total sugar contents before and after storage $\left(\mathrm{g} \mathrm{kg}^{-1}\right.$; mean $\left.\pm \mathrm{SE} ; n=15\right)$ of two Capsicum cultivars (two fruit parts) infested with $H$. halys.

\begin{tabular}{|c|c|c|c|c|c|c|c|c|}
\hline & & & \multicolumn{3}{|l|}{ Before Storage } & \multicolumn{3}{|l|}{ After Storage } \\
\hline & & & Control & H. halys & Control 2 & Control & H. halys & Control 2 \\
\hline \multirow{8}{*}{$\begin{array}{l}\text { Pungent } \\
\text { 'Eris F1' }\end{array}$} & \multirow{4}{*}{ Pericarp } & Sucrose & $118.2 \pm 4.3$ & $126.3 \pm 8.4$ & $81.0 \pm 9.3$ & $98.1 \pm 6.7$ & $129.2 \pm 16.9$ & $96.0 \pm 5.9$ \\
\hline & & Glucose & $224.5 \pm 8.4 \mathrm{a}^{i}$ & $215.1 \pm 17.5 \mathrm{a}$ & $141.4 \pm 8.8 b$ & $150.2 \pm 4.7 \mathrm{~b}$ & $232.1 \pm 19.0 \mathrm{a}$ & $177.5 \pm 10.5 \mathrm{a}$ \\
\hline & & Fructose & $285.2 \pm 14.2$ & $249.3 \pm 18.8$ & $212.2 \pm 11.2$ & $207.2 \pm 6.3$ & $269.3 \pm 24.6$ & $224.3 \pm 7.3$ \\
\hline & & Total sugars & $627.9 \pm 31.7$ a & $590.7 \pm 25.1$ a & $439.6 \pm 14.4 b$ & $455.5 \pm 21.7 b$ & $634.6 \pm 51.3 \mathrm{a}$ & $497.8 \pm 41.6 b$ \\
\hline & \multirow{4}{*}{ Placenta } & Sucrose & $143.4 \pm 5.0$ & $124.3 \pm 31.0$ & $73.2 \pm 12.2$ & $76.0 \pm 10.2$ & $109.0 \pm 9.6$ & $89.0 \pm 8.2$ \\
\hline & & Glucose & $222.3 \pm 8.4$ & $160.0 \pm 21.8$ & $68.6 \pm 8.9$ & $83.5 \pm 14.7$ & $190.4 \pm 21.2$ & $98.0 \pm 12.7$ \\
\hline & & Fructose & $333.1 \pm 10.2 \mathrm{a}$ & $222.1 \pm 34.2 \mathrm{~b}$ & $141.0 \pm 11.7 \mathrm{c}$ & $136.2 \pm 18.4 \mathrm{~b}$ & $267.2 \pm 30.5 a$ & $154.1 \pm 11.5 \mathrm{~b}$ \\
\hline & & Total sugars & $698.8 \pm 52.7 \mathrm{a}$ & $506.4 \pm 24.5 b$ & $282.8 \pm 19.4 \mathrm{c}$ & $295.7 \pm 25.8 b$ & $566.6 \pm 42.6 \mathrm{a}$ & $341.2 \pm 36.2 b$ \\
\hline \multirow{7}{*}{$\begin{array}{l}\text { Non-pungent } \\
\text { 'Lombardo tago' }\end{array}$} & \multirow{4}{*}{ Pericarp } & Sucrose & $68.0 \pm 2.0$ & $75.5 \pm 6.8$ & $77.1 \pm 6.2$ & $55.3 \pm 14.4$ & $81.3 \pm 5.3$ & $66.2 \pm 5.4$ \\
\hline & & Glucose & $265.5 \pm 5.4 \mathrm{a}$ & $228.3 \pm 13.0 \mathrm{~b}$ & $261.6 \pm 12.7 \mathrm{a}$ & $152.1 \pm 29.1 \mathrm{~b}$ & $277.1 \pm 19.6 \mathrm{a}$ & $172.1 \pm 20.2 \mathrm{~b}$ \\
\hline & & Fructose & $351.0 \pm 8.7$ & $332.1 \pm 16.5$ & $372.2 \pm 11.5$ & $229.3 \pm 47.4 \mathrm{~b}$ & $366.5 \pm 14.1 \mathrm{a}$ & $257.1 \pm 33.4 \mathrm{~b}$ \\
\hline & & Total sugars & $684.5 \pm 36.0 \mathrm{a}$ & $635.9 \pm 52.3 \mathrm{~b}$ & $710.9 \pm 55.3 \mathrm{a}$ & $436.7 \pm 24.2 \mathrm{~b}$ & $724.9 \pm 63.4 \mathrm{a}$ & $495.4 \pm 32.8 \mathrm{~b}$ \\
\hline & \multirow{3}{*}{ Placenta } & Sucrose & $95.4 \pm 6.7 \mathrm{a}$ & $88.2 \pm 8.6 \mathrm{a}$ & $52.3 \pm 5.6 b$ & $49.0 \pm 2.4 b$ & $78.0 \pm 6.2 \mathrm{a}$ & $86.1 \pm 12.7 \mathrm{a}$ \\
\hline & & Glucose & $194.5 \pm 13.2 \mathrm{a}$ & $125.5 \pm 5.2 b$ & $127.5 \pm 12.2 \mathrm{~b}$ & $104.2 \pm 6.7$ & $118.2 \pm 20.9$ & $99.3 \pm 11.6$ \\
\hline & & Fructose & $323.0 \pm 21.6 \mathrm{a}$ & $199.1 \pm 7.5 \mathrm{~b}$ & $232.1 \pm 19.1 \mathrm{a}$ & $176.1 \pm 24.8$ & $185.2 \pm 26.4$ & $174.4 \pm 8.6$ \\
\hline
\end{tabular}

${ }^{i} \mathrm{a}, \mathrm{b}, \mathrm{c}$ different letters denote statistically significant differences $(\alpha \leq 0.05)$ among treatments in the same cultivar and fruit part. 
After storage, total sugar contents decreased in the Control 1 treatment. However, $H$. halys and Control 2 treatment sugar content increased slightly in the pericarp of the 'Eris F1' cultivar. This also happened with glucose in the pericarp and fructose in the placenta of 'Eris F1'.

In the 'Lombardo tago' pericarp, the H. halys treatment after storage contained approximately $66 \%$ more total sugars than in the Control 1 treatment and $46.3 \%$ more than in the Control 2 treatment.

\subsection{Individual and Total Organic Acid Contents}

Seven organic acids were determined in pungent and non-pungent peppers (Table 3). Oxalic acid was not detected in the pericarp of either cultivar.

Regarding individual and total organic acids contents, the placenta of pungent 'Eris F1' was affected significantly by $H$. halys (Wilks' $\lambda=0.095, \mathrm{~F}=10.68, p=0.009$ ), but the pericarp was not (Wilks' $\lambda=0.395, \mathrm{~F}=0.74, p=0.289$ ). After storage, the pericarp and placenta were affected significantly by $H$. halys (Wilks' $\lambda=0.079, \mathrm{~F}=15.91, p<0.001$ ).

The non-pungent 'Lombardo tago' pericarp and placenta were affected by $H$. halys (Wilks' $\lambda=0.042, F=7.89, p=0.005$ ). Similar results were also present after storage (Wilks' $\lambda=0.055, \mathrm{~F}=9.01, p=0.008$ ).

In the pungent cultivar 'Eris $\mathrm{F}^{\prime}$ ', the $H$. halys presence was more noticeable in the placenta. Compared to the Control 1 treatment, $H$. halys reduced citric acid content by $21.4 \mathrm{~g} \mathrm{~kg}^{-1}$ in the placenta of fruit before storage. It increased fumaric acid content in fruit both before and after storage.

Halyomorpha halys had a significantly more noticeable effect on organic acids in the pericarp of non-pungent 'Lombardo tago'. Before storage, $H$. halys increased quinic acid and fumaric acid content by $15.1 \%$, and $161.7 \%$, respectively, in the pericarp. After storage, malic acid and fumaric acid increased in $H$. halys-attacked fruit. Quinic acid content increased during storage, and the Control 1 treatment had $19.2 \mathrm{~g} \mathrm{~kg}^{-1}$ more quinic acid after storage compared to the H. halys treatment. The placenta of the non-pungent 'Lombardo tago' showed no differences among organic acid contents, except for ascorbic acid.

Ascorbic acid content was not affected by $H$. halys in either pungent or non-pungent cultivars' pericarps. On the other hand, H. halys had a significant impact on placenta ascorbic acid content. In the pungent cultivar 'Eris F1', the Control 1 treatment before storage had $75.0 \%$ higher ascorbic acid content than in the $H$. halys treatment and after storage $64.9 \%$, although storage negatively impacted all treatments in terms of ascorbic acid content in the placenta and pericarp.

$H$. halys decreased ascorbic acid content in the placenta of non-pungent 'Lombardo tago' before storage by $27.9 \%$. After storage, the $H$. halys treatment had $27.0 \%$ less ascorbic acid in the placenta than in the Control 1 treatment. H. halys had no effect on ascorbic acid content in the pericarp of either cultivar 
Table 3. Individual and total organic acid contents before and after storage ( $\mathrm{g} \mathrm{kg}^{-1}$; mean $\pm \mathrm{SE} ; n=15$ ) of two Capsicum cultivars (two fruit parts) infested with $H$. halys.

\begin{tabular}{|c|c|c|c|c|c|c|c|c|}
\hline & & & \multicolumn{3}{|l|}{ Before Storage } & \multicolumn{3}{|l|}{ After Storage } \\
\hline & & & Control & H. halys & Control 2 & Control & H. halys & Control 2 \\
\hline \multirow{16}{*}{$\begin{array}{l}\text { Pungent } \\
\text { 'Eris F1' }\end{array}$} & \multirow{8}{*}{ Pericarp } & Oxalic acid & / & / & / & / & / & 1 \\
\hline & & Citric acid & $46.5 \pm 2.4$ & $45.4 \pm 2.4$ & $47.7 \pm 8.2$ & $23.9 \pm 1.7 \mathrm{~b}$ & $27.2 \pm 1.3 \mathrm{ab}$ & $31.6 \pm 2.3 \mathrm{a}$ \\
\hline & & Malic acid & $14.2 \pm 0.6$ & $13.3 \pm 0.5$ & $14.5 \pm 2.6$ & $17.4 \pm 1.3 \mathrm{~b}$ & $26.6 \pm 3.4 \mathrm{a}$ & $17.2 \pm 1.2 \mathrm{~b}$ \\
\hline & & Qunic acid & $21.6 \pm 2.2$ & $15.6 \pm 1.2$ & $14.3 \pm 2.2$ & $16.6 \pm 1.5$ & $13.4 \pm 1.3$ & $14.4 \pm 1.5$ \\
\hline & & Succinic acid & $5.2 \pm 0.5$ & $5.0 \pm 0.8$ & $5.8 \pm 0.5$ & $5.0 \pm 0.2$ & $5.4 \pm 0.5$ & $6.0 \pm 0.3$ \\
\hline & & Fumaric acid & $42.4 \pm 3.8$ & $46.6 \pm 3.5$ & $45.2 \pm 9.3$ & $52.4 \pm 7.6 \mathrm{~b}$ & $110.2 \pm 2.3 \mathrm{a}$ & $63.4 \pm 6.8 \mathrm{~b}$ \\
\hline & & Ascorbic acid & $35.2 \pm 4.3$ & $33.5 \pm 5.3$ & $44.5 \pm 3.6$ & $23.4 \pm 1.4$ & $19.2 \pm 1.3$ & $19.2 \pm 1.6$ \\
\hline & & Total acids & $122.7 \pm 13.6$ & $111.2 \pm 13.5$ & $125.3 \pm 13.7$ & $85.7 \pm 5.3 b$ & $91.2 \pm 4.6 \mathrm{a}$ & $88.5 \pm 2.3 b$ \\
\hline & \multirow{8}{*}{ Placenta } & Oxalic acid $\downarrow$ & $217.2 \pm 36.3$ & $148.6 \pm 9.6$ & $211.8 \pm 10.2$ & $468.4 \pm 68.2$ & $419.6 \pm 5.6$ & $454.4 \pm 2.5$ \\
\hline & & Citric acid & $67.6 \pm 2.7 \mathrm{a}^{i}$ & $46.2 \pm 6.8 b$ & $45.4 \pm 3.3 \mathrm{~b}$ & $36.5 \pm 4.6$ & $32.3 \pm 2.7$ & $29.3 \pm 3.5$ \\
\hline & & Malic acid & $26.3 \pm 1.3$ & $20.7 \pm 3.6$ & $21.5 \pm 3.8$ & $41.7 \pm 6.5$ & $42.7 \pm 8.2$ & $31.6 \pm 4.2$ \\
\hline & & Qunic acid & $12.2 \pm 0.8$ & $9.9 \pm 1.3$ & $9.7 \pm 1.7$ & $12.3 \pm 1.4$ & $12.9 \pm 0.3$ & $11.5 \pm 2.6$ \\
\hline & & Succinic acid & $6.7 \pm 0.2$ & $5.4 \pm 0.5$ & $6.2 \pm 1.7$ & $6.5 \pm 0.2$ & $5.7 \pm 0.5$ & $6.2 \pm 0.2$ \\
\hline & & Fumaric acid & $70.4 \pm 4.6 \mathrm{~b}$ & $114.5 \pm 13.3 \mathrm{a}$ & $136.7 \pm 13.6 \mathrm{a}$ & $125.4 \pm 9.8$ & $204.2 \pm 23.3$ & $215.8 \pm 8.6$ \\
\hline & & Ascorbic acid & $20.3 \pm 1.3 \mathrm{a}$ & $11.6 \pm 1.8 \mathrm{~b}$ & $7.7 \pm 1.5 \mathrm{~b}$ & $12.2 \pm 1.3$ & $7.4 \pm 1.6 b$ & $8.1 \pm 1.3 b$ \\
\hline & & Total acids & $131.2 \pm 10.6 \mathrm{a}$ & $92.4 \pm 4.3 \mathrm{~b}$ & $90.5 \pm 5.6 \mathrm{~b}$ & $109.6 \pm 9.5 \mathrm{a}$ & $100.2 \pm 3.8 \mathrm{a}$ & $87.5 \pm 2.2 \mathrm{a}$ \\
\hline \multirow{15}{*}{$\begin{array}{l}\text { Non-pungent } \\
\text { 'Lombardo tago' }\end{array}$} & \multirow{7}{*}{ Pericarp } & Citric acid & $36.1 \pm 1.2$ & $42.4 \pm 2.4$ & $40.5 \pm 2.3$ & $34.2 \pm 4.4$ & $35.2 \pm 1.2$ & $27.3 \pm 6.2$ \\
\hline & & Malic acid & $16.4 \pm 1.5$ & $17.3 \pm 1.6$ & $17.6 \pm 0.6$ & $25.4 \pm 2.2 \mathrm{~b}$ & $35.8 \pm 2.6 \mathrm{a}$ & $21.5 \pm 5.5 b$ \\
\hline & & Qunic acid & $15.2 \pm 0.2 b$ & $17.5 \pm 1.1 \mathrm{a}$ & $12.2 \pm 1.5 b$ & $45.5 \pm 3.6 \mathrm{a}$ & $26.3 \pm 3.4 b$ & $22.8 \pm 2.6 \mathrm{~b}$ \\
\hline & & Succinic acid & $4.0 \pm 0.2$ & $5.0 \pm 0.4$ & $5.1 \pm 0.2$ & $5.2 \pm 0.1$ & $5.7 \pm 0.4$ & $5.2 \pm 0.3$ \\
\hline & & Fumaric acid & $34.2 \pm 1.6 \mathrm{~b}$ & $89.5 \pm 8.2 \mathrm{a}$ & $86.8 \pm 7.3 \mathrm{a}$ & $63.8 \pm 7.7 b$ & $100.5 \pm 14.2 \mathrm{a}$ & $71.9 \pm 6.2 b$ \\
\hline & & Ascorbic acid & $30.5 \pm 1.7$ & $31.2 \pm 1.5$ & $33.4 \pm 0.3$ & $26.2 \pm 0.6$ & $23.2 \pm 1.2$ & $25.4 \pm 1.4$ \\
\hline & & Total acids & $102.4 \pm 5.4 \mathrm{~b}$ & $112.6 \pm 10.1 \mathrm{a}$ & $107.2 \pm 9.0 \mathrm{~b}$ & $135.7 \pm 11.2$ & $125.1 \pm 10.6$ & $101.4 \pm 8.0$ \\
\hline & \multirow{8}{*}{ Placenta } & Oxalic acid $\downarrow$ & $103.4 \pm 10.6$ & $84.7 \pm 2.8$ & $70.6 \pm 1.0$ & $320.4 \pm 10.0$ & $540.6 \pm 9.3$ & $439.3 \pm 8.0$ \\
\hline & & Citric acid & $40.3 \pm 3.3$ & $37.5 \pm 3.4$ & $32.8 \pm 4.2$ & $34.2 \pm 5.3$ & $36.5 \pm 2.4$ & $31.2 \pm 2.2$ \\
\hline & & Malic acid & $23.6 \pm 2.5$ & $32.3 \pm 7.2$ & $19.2 \pm 3.5$ & $30.5 \pm 2.5$ & $40.2 \pm 6.7$ & $22.6 \pm 4.5$ \\
\hline & & Qunic acid & $7.3 \pm 1.8$ & $5.4 \pm 1.9$ & $5.4 \pm 1.3$ & $8.1 \pm 3.7$ & $17.4 \pm 2.3$ & $15.2 \pm 3.7$ \\
\hline & & Succinic acid & $5.8 \pm 0.2$ & $5.6 \pm 0.3$ & $5.1 \pm 0.2$ & $5.2 \pm 0.4$ & $5.2 \pm 0.3$ & $6.4 \pm 0.4$ \\
\hline & & Fumaric acid & $71.5 \pm 0.4 b$ & $152.3 \pm 17.4 \mathrm{a}$ & $128.6 \pm 3.3 \mathrm{a}$ & $172.3 \pm 5.8$ & $162.5 \pm 12.7$ & $198.6 \pm 5.4$ \\
\hline & & Ascorbic acid & $15.4 \pm 0.7 \mathrm{a}$ & $11.1 \pm 0.7 \mathrm{~b}$ & $11.3 \pm 1.4 \mathrm{~b}$ & $14.4 \pm 0.3 \mathrm{a}$ & $10.5 \pm 0.1 \mathrm{~b}$ & $11.2 \pm 1.0 \mathrm{~b}$ \\
\hline & & Total acids & $90.8 \pm 4.3$ & $91.9 \pm 6.5$ & $71.3 \pm 2.6$ & $92.4 \pm 4.3 \mathrm{~b}$ & $109.5 \pm 3.7 \mathrm{a}$ & $86.2 \pm 5.6 b$ \\
\hline
\end{tabular}

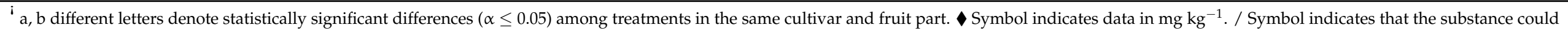
not be determined. 


\subsection{Individual and Total Phenolics Contents}

Individual phenolics are presented Tables S1 and S2, and total phenolics are presented in Figure 2. Regarding individual and total phenolic contents, the placenta and pericarp of pungent 'Eris F1' were not affected significantly by $H$. halys (Wilks' $\lambda=0.295, F=0.85$, $p=0.422)$ in terms of total phenolics, but only certain individual phenolics in both fruit parts (Wilks' $\lambda=0.091, \mathrm{~F}=6.44, p=0.021$ ). After storage, the pericarp and placenta were not affected significantly by $H$. halys (Wilks' $\lambda=0.224, \mathrm{~F}=0.81, p=0.352$ ). The non-pungent 'Lombardo tago' pericarp and placenta were affected by H. halys (Wilks' $\lambda=0.005, \mathrm{~F}=16.85$, $p<0.001)$ for individual and total phenolics. After storage, only the pericarp showed statistical differences and not the placenta. (Wilks' $\lambda=0.099, \mathrm{~F}=6.01, p=0.018$ ). No differences were observed in total phenolic content (TPC) or total analyzed phenolics in pungent 'Eris F1'. Certain individual phenolics were positively impacted by $H$. halys. Before storage, luteolin-6,8-di-C-hexoside was the only phenolic impacted by the $H$. halys in the pungent cultivar pericarp, with an increase of $46.6 \mathrm{mg} \mathrm{kg}^{-1}$ (compared to the control) and $37.4 \mathrm{mg} \mathrm{kg}^{-1}$ (compared to the Control 2). In the placenta, H. halys increased luteolin7-O-(2-apiosyl-6-malonyl) hexoside content and decreased luteolin-7-O-(2-apiosyl-6-acetyl) hexoside. After storage of pungent cultivar 'Eris F1', the placenta showed no differences among treatments. In the pericarp, a statistical increase was found in luteolin-6-C-hexoside and luteolin-6,8-di-C-hexoside in $H$. halys-attacked fruit.

Non-pungent 'Lombardo tago' individual and total phenolic contents were more impacted by the $\mathrm{H}$. halys attack. In the pericarp before storage, luteolin 6-C-hexoside-8C-pentoside 2, chrysoeriol 7-O-(2-apiosyl-6-acetyl) glucoside, apigenin 6-C-hexoside-8-Cpentoside 1, and apigenin 6,8 di-C-hexoside contents increased compared to the Control 1 and Control 2 treatments. H. halys increased total flavone and flavonol contents. H. halys increased total phenolic (pericarp before storage) contents by $1.9 \mathrm{~g}$ and $1.6 \mathrm{~g} \mathrm{~kg}^{-1}$ compared to the Control 1 and Control 2 treatments, respectively. In the placenta of 'Lombardo tago', phenolics contents (where statistical differences were present) decreased in the H. halys infested plants compared to the Control 1 treatment.

After storage, most phenolics decreased in contents compared to the pre-storage contents in the non-pungent 'Lombardo tago' cultivar pericarp. Total analyzed phenolics in the pericarp were $0.2 \mathrm{~g} \mathrm{~kg}^{-1}$ and $0.1 \mathrm{~g} \mathrm{~kg}^{-1}$ lower in the $H$. halys treatment than in the Control 1 and Control 2 treatments, respectively. Total phenolic contents increased by $2.4 \mathrm{~g} \mathrm{~kg}^{-1}$ in the H. halys-attacked fruit compared to the Control 1 treatment.

\subsection{Individual and Total Capsaicinoid Contents}

All five capsaicinoids were positively affected by the $H$. halys attack in the pericarp of the pungent cultivar 'Eris F1' (Table S3). Regarding individual and total capsaicinoids contents, the placenta and pericarp of the pungent 'Eris $\mathrm{F}^{\prime}$ ' were affected significantly by H. halys (Wilks' $\lambda=0.077, \mathrm{~F}=17.35, p<0.001$ ). After storage, the pericarp and placenta were affected significantly by $H$. halys (Wilks' $\lambda=0.052, \mathrm{~F}=10.44, p=0.001$ ). The non-pungent 'Lombardo tago' pericarp and placenta were affected by $H$. halys (Wilks' $\lambda=0.005, \mathrm{~F}=16.85$, $p<0.001)$ for individual and total capsaicinoids. After storage, only the pericarp showed statistical differences and not the placenta, in terms of total capsaicinoids (Wilks' $\lambda=0.073$, $\mathrm{F}=9.22, p=0.008$ )

The healthy plants of the Control 1 treatment had approximately 15 times less total capsaicinoids than the $H$. halys infested plants and approximately 5 times less total capsaicinoids than Control 2 plants (Figure 3). Accumulation of total capsaicinoids in the placenta of 'Eris F1' before storage was statistically and significantly impacted by $H$. halys, with $14.0 \mathrm{~g} \mathrm{~kg}^{-1}$ and $25.3 \mathrm{~g} \mathrm{~kg}^{-1}$ higher capsaicinoid contents compared to the Control 1 and Control 2, respectively. 


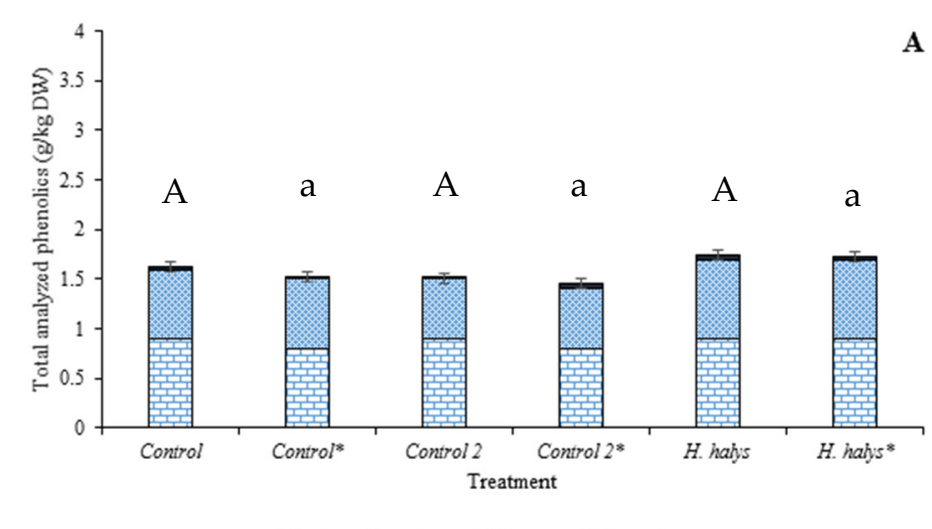

口Hydroxycinnamic a EFlavone -Flavonols

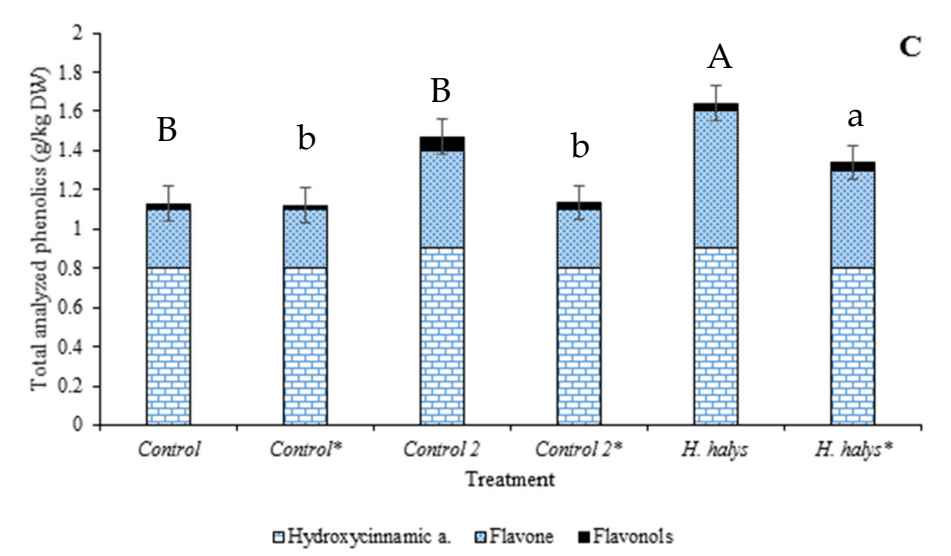

A

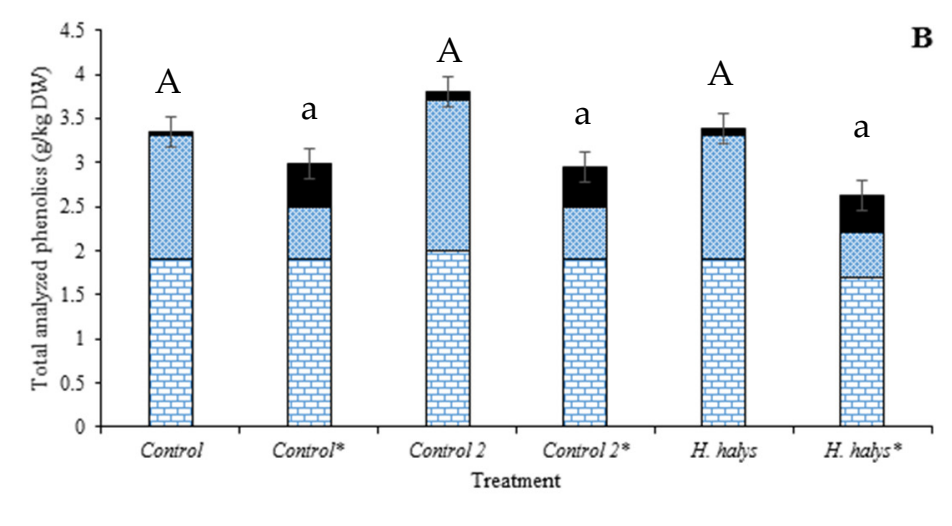

DHydroxycinnamic a aFlavone -Flavonols

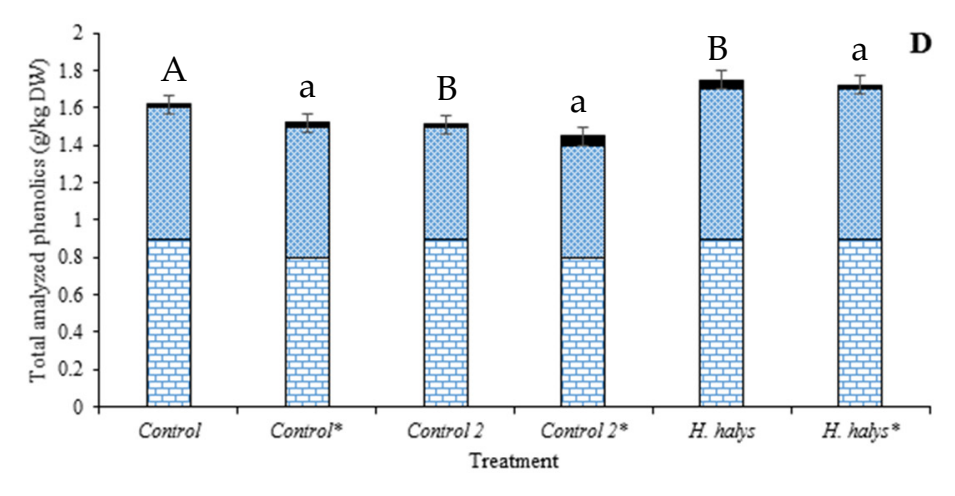

DHydroxycinnamic a. EFlavone - Flavonols

B

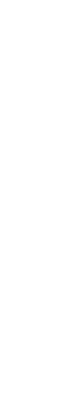



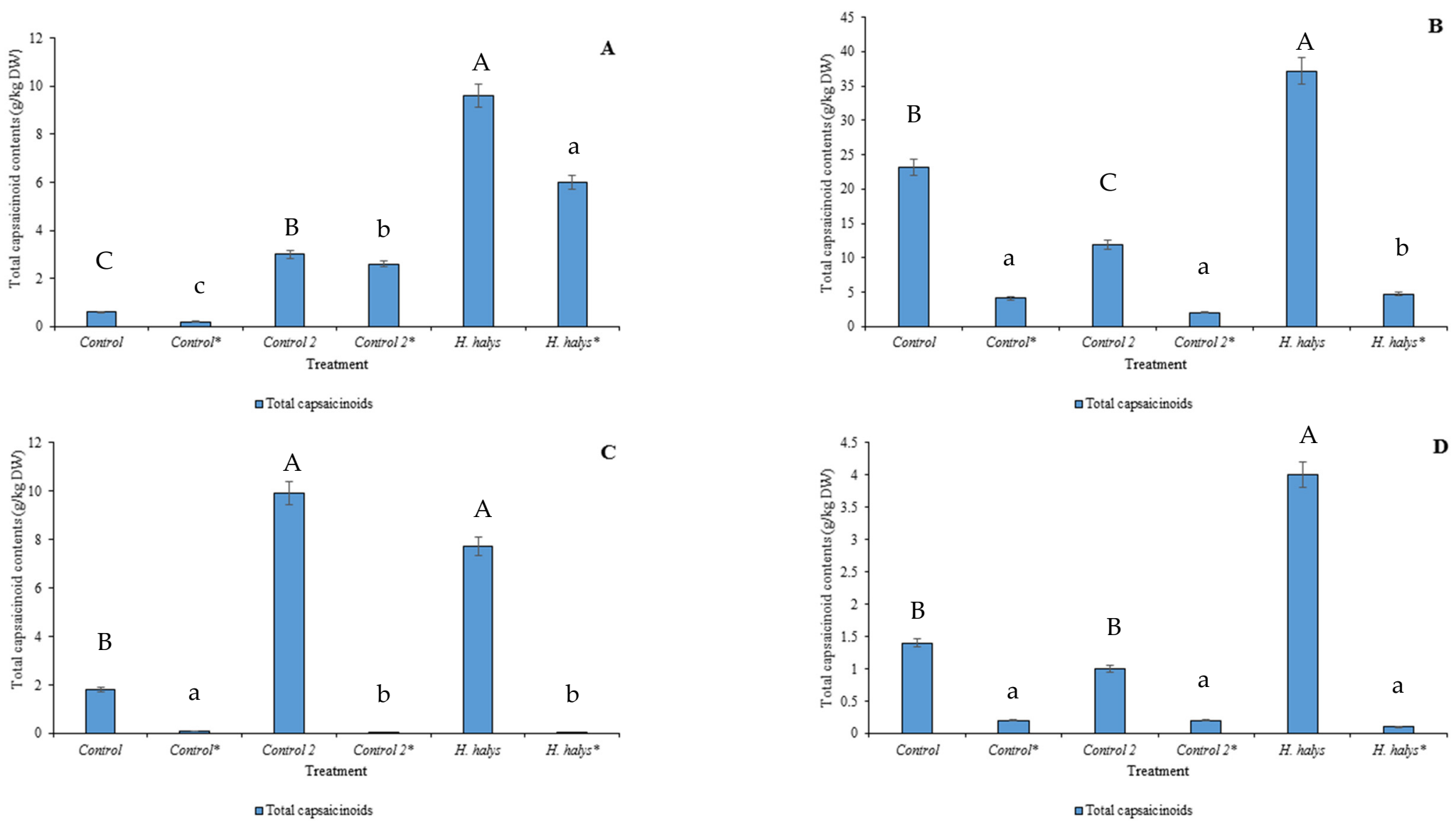

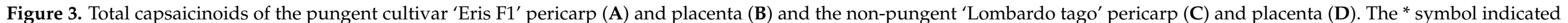

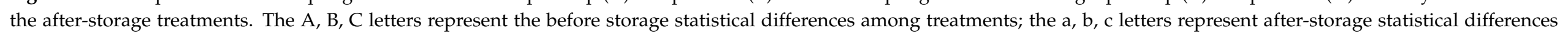
among treatments. 
After storage, all capsaicinoid contents dropped, although $H$. halys treatment still had the highest total capsaicinoid content in the pericarp of the 'Eris F1' cultivar. In the placenta, the total capsaicinoid level dropped to $2.0 \mathrm{~g} \mathrm{~kg}^{-1}$ in the $H$. halys treatment, resulting in $2.1 \mathrm{~g}$ and $2.7 \mathrm{~g} \mathrm{~kg}^{-1}$ lower concentrations when compared to the Control 1 and Control 2 treatments, respectively.

Dihydrocapsaicin, nordihydrocapsaicin, homocapsaicin, and homodihydrocapsaicin were all higher in the $H$. halys treatment than in the Control 1 plants in the non-pungent 'Lombardo tago' cultivar pericarp. No differences were observed between the H. halys treatment and the Control 2 treatment. All capsaicinoids in the placenta were higher in the H. halys treatment than in the Control 1 and Control 2, except for nordihydrocapsaicin. The total capsaicinoid contents in the placenta of 'Lombardo tago' increased almost four times compared to both controls.

After storage, the non-pungent 'Lombardo tago' lost most of its pungency. The total capsaicinoids in the pericarp were higher in the Control 1 treatment and lower in the other two treatments (Figure 3 and Table S3). The placenta after storage lost most of its capsaicinoids, and no differences were observed among treatments.

\section{Discussion}

We tested the potential of the brown marmorated stink bug (Halyomorpha halys Stål.) to induce a plant response after feeding/damaging pepper fruits, in terms of primary and secondary metabolites. In our experiment, we infested two cultivars of peppers, pungent 'Eris F1' and non-pungent 'Lombardo tago'. We made an analysis of individual sugars, organic acids, phenolics, and capsaicinoids of fresh peppers, and those after 28 days storage, to see whether there is any impact of $H$. halys also after storage. We observed a change in individual sugar contents and total sugar content in the fresh fruit before and after storage in both cultivars. Where statistical differences were present, glucose was the most affected sugar of all three determined. Sugars are known to be signaling molecules in plants [35]. Morkunas and Ratajczak [35] also reported that plants with higher sugar contents are more resistant to pests and disease attacks. Glucose and sucrose both act as signaling molecules, of which sucrose affects gene expression [36]. Major differences were observed between the two cultivars in terms of the response to the insect attack. This is mainly due to genetic variation among species and cultivars of plants. An insect infestation or infection of pathogenic fungi always impacts the sugar metabolism in plants, although this response greatly varies from the host-pests' system [35]. In our case, we observed a significant decrease of total sugars in the H. halys-infested non-pungent 'Lombardo tago'. On the other hand, in the pungent 'Eris F1', the H. halys treatment increased sugar content only when compared to the Control 2 treatment, and no changes were observed compared to the Control 1 treatment, which may indicate that the sugar synthesis response was on the entire plant. A possible explanation of this occurrence could be the genetic variability within the cultivar, or that sugars could be translocated to the infested fruit [37]. Another reason may be that more sugars were consumed for energy, since the infested plants had to battle an insect attack $[35,36]$, or they were used in other synthesis pathways, such as the shikimic pathway or phenylpropanoid pathway [38]. Naturally, a certain percent of sugars is also consumed by the pathogen or insect.

After storage, a general decrease in all metabolites was observed in both cultivars. Interestingly, a noticeable decrease of total sugars was observed in the Control 1 treatment and an increase in $H$. halys infested plants. A possible reason for this may be that due to $H$. halys feeding, the plant reacted with the synthesis of thicker cell walls to prevent damage. Cell walls and other cell parts are broken down during ripening or storage, which results in higher sugar contents [39].

Total organic acids in the placenta of 'Eris F1' decreased in the H. halys treatment compared to the Control 1 treatment. Fumaric acid was lower in the Control 1 treatment compared to the other two treatments. Fumaric acid plays multiple roles in a plant. It fuels cellular respiration or functions as an alternative carbon sink for photosynthate [40]. In 
total organic acid contents, major differences were observed between the two cultivars, which indicates how a plant response to insect attacks is also cultivar based. After storage significant differences were observed in total organic acid content, the $H$. halys treatment had higher total organic acid content than in both control treatments. Similar results were reported by Zushi and Matsuzoe [41], where stressed tomato plants had higher organic acid contents after storage compared to the control. After storage, we observed an increase in malic acid in the $H$. halys-attacked fruit. Similar results were reported by Leiss, et al. [42], that malic acid content increased when western flower thrips (Frankliniella occidentalis) attacked chrysanthemum (Dendranthema grandiflora).

There was not an overall strong reaction in terms of phenolic response in the pungent 'Eris F1' cultivar. Among 16 determined individual phenolics, only luteolin-6,8-di-Chexoside changed in the pericarp of the pungent 'Eris F1' and luteolin-7-O-(2-apiosyl-6acetyl) hexoside and luteolin-7-O-(2-apiosyl-6-malonyl) hexoside in the placenta. After post-storage, three individual phenolics (luteolin-6-C-hexoside, luteolin 6,8-di-C-hexoside, and quercetin-3-O-rhamnoside) also had significant differences among treatments, whereby both luteolins were highest in the $H$. halys treatment. On the other hand, the non-pungent 'Lombardo tago' had a much greater phenolic response to the H. halys attack. Before storage, flavonols and flavones increased in both fruit parts. The $H$. halys increased total phenolic content in the pericarp of 'Lombardo tago' and decreased TPC in the placenta before storage. After storage, seven individual phenolics in the pericarp of 'Lombardo tago' increased in the $H$. halys treatment compared to the Control 1 treatment. The effect of $H$. halys was less noticeable in the placenta of 'Lombardo tago' after storage, with only two individual phenolics being impacted by its attack, compared to the Control 1 treatment. An increase of phenolics is common, since they are one of the main defense molecules against biotic and abiotic stressors [43], which was also demonstrated by our results. Flavonoids are well known to be defense molecules in plants [44]. In our study, we observed an increase in individual phenolics such as luteolins, which are a part of flavones. Flavones are known to be defense molecules, as previously noted by Soriano, Asenstorfer, Schmidt, and Riley [23], who reported an increased synthesis of flavones as a response to an invasion by parasitic nematodes in oats (Avena sativa). High levels of flavones are also present in silks of maize (Zea mays), which increase the resistance to corn earworm [45]. Flavonoids can deter or attract insects. They can protect the plant from herbivores or sucking insects, since they can alter the palatability of the plants, reducing their nutritive value, and they can decrease digestibility or act as toxins [43]. A similar pattern was observed in our study, whereby the pepper plants (especially non-pungent 'Lombardo tago') infested with H. halys reacted with an increased accumulation of flavones and flavanols, especially luteolins.

A possible reason for the less noticeable reaction of the pungent 'Eris F1' in terms of phenolics is its capability to synthesize high capsaicinoid levels. Capsaicinoids consist of a phenolic structure (phenylpropanoid way) and fatty acid (fatty acid metabolism) [46]. Phenolics can be used to synthesize capsaicinoids, which would explain why the $H$. halys effect on phenolics was not as noticeable in the pungent 'Eris F1' as in the non-pungent 'Lombardo tago' cultivar.

$H$. halys increased total capsaicinoids and, in most cases, also individual capsaicinoids in all before storage treatments, compared to both control treatments. After storage, individual capsaicinoids dropped in both cultivars. Interestingly, the placenta of 'Eris F1' dropped from high capsaicinoid contents in the $H$. halys treatment to low after storage. Capsaicinoids are known to be repellents for mammals and other animals [47]. Capsaicin acts as a Drosophila ovipositional repellent, and it influences their lifespan, climbing behavior, and digestive tracts [22]. Capsaicin has also been shown to be an onion fly ovipositional deterrent, impacting the insects' thermoregulation, which can cause a change in the behavior of the insect, especially with breeding or laying eggs [48-50]. 


\section{Conclusions}

Our study provides a detailed insight into the pre- and post-harvest quality of hot and non-hot peppers infested with the brown marmorated stink bug (H. halys). We were able to confirm that both cultivars responded to the $H$. halys infestation with an increase in metabolites, particularly phenolics and capsaicinoids, indicating that infestation had occurred even though visual damage was not observed. The observation of an increase in capsaicinoid synthesis in the infested fruit indicates that capsaicinoids may have a defensive function against $H$. halys and could be an interesting area of investigation for further experimentation. After storage, all metabolite levels decreased, although the $H$. halys treatments still had the highest metabolite levels, showing us that the effect of $H$. halys feeding on pepper fruits lasts longer, even after the insects have long disappeared.

Supplementary Materials: The following are available online at https:/ / www.mdpi.com/article / 10.3390/agronomy11112252/s1, Table S1: Individual and total phenolic contents of pungent cultivar 'Eris F1' before $(\mathbf{A})$ and after storage $(\mathbf{B})\left(\mathrm{mg} \mathrm{kg}^{-1}\right.$; mean $\left.\pm \mathrm{SE} ; n=15\right)$ infested with $H$. halys. Table S2: Individual and total phenolic contents of non-pungent cultivar 'Lombardo tago' before (A) and after storage (B) $\left(\mathrm{mg} \mathrm{kg}^{-1}\right.$; mean $\left.\pm \mathrm{SE} ; n=15\right)$ infested with $H$. halys. Table S3: Individual and total capsaicinoid contents before and after storage of pungent 'Eris $\mathrm{F}^{\prime}$ ' (A) and non-pungent 'Lombardo tago' (B) $\left(\mathrm{mg} \mathrm{kg}^{-1}\right.$; mean $\left.\pm \mathrm{SE} ; n=15\right)$ infested with $H$. halys.

Author Contributions: T.Z. wrote the manuscript, performed the statistical analysis, and laboratory work. A.S. carried out the field experiment section of the experiment and checked the manuscript for errors. R.V. and M.H. checked the grammar, statistical approach, and read the manuscript for technical errors. All authors have read and agreed to the published version of the manuscript.

Funding: This work is part of the program Horticulture P4-0013-0481 supported by the Slovenian Research Agency.

Institutional Review Board Statement: Not applicable.

Informed Consent Statement: Not applicable.

Data Availability Statement: The data presented in this study are available on request from the corresponding author. The data are not publicly available due to privacy.

Conflicts of Interest: The authors declare that they have no known competing financial interest or personal relationship that could appear to have influenced the work reported here.

\section{References}

1. Penella, C.; Calatayud, A. Pepper Crop under Climate Change: Grafting as an Environmental Friendly Strategy. In Climate Resilient Agriculture: Strategies and Perspectives; IntechOpen: London, UK, 2018.

2. Bicikliski, O.; Trajkova, F.; Mihajlov, L.; Jordanovska, S.; Tashev, K. Vitamin C and Total Antioxidant Content in Pepper Fruits (Capsicum annuum L.): Comparative Analysis of Peppers Grown in Conventional and Organic Agricultural Systems. Annu. Res. Rev. Biol. 2018, 27, 1-11. [CrossRef]

3. Cronin, J.R. The Chili Pepper's Pungent Principle: Capsaicin Delivers Diverse Health Benefits. Altern. Complement. Ther. 2002, 8, 110-113. [CrossRef]

4. Zamljen, T.; Zupanc, V.; Slatnar, A. Influence of irrigation on yield and primary and secondary metabolites in two chilies species, Capsicum annuum L. and Capsicum chinense Jacq. Agric. Water Manag. 2020, 234, 106104. [CrossRef]

5. Daryanto, A.; Syukur, M.; Hidayat, P.; Maharijaya, A. Antixenosis and antibiosis based resistance of chili pepper to melon aphid. J. Appl. Hort 2017, 19, 147-151. [CrossRef]

6. Johari, A.; Herlinda, S.; Irsan, C.; Pujiastuti, Y. Phenomenon of Thrips (Thysanoptera) Attack on Chili Plant (Capsicum annuum L.). Am. J. Agric. Biol. Sci. 2016, 11, 103-109. [CrossRef]

7. Moreau, T.L.; Isman, M.B. Combining reduced-risk products, trap crops and yellow sticky traps for greenhouse whitefly (Trialeurodes vaporariorum) management on sweet peppers (Capsicum annum). Crop Prot. 2012, 34, 42-46. [CrossRef]

8. Wermelinger, B.; Wyniger, D.; Forster, B. First records of an invasive bug in Europe: Halyomorpha halys Stal (Heteroptera: Pentatomidae), a new pest on woody ornamentals and fruit trees? Mitt. Schweiz. Entomol. Ges. 2007, 81, 1.

9. Zhou, Y.; Giusti, M.M.; Parker, J.; Salamanca, J.; Rodriguez-Saona, C. Frugivory by Brown Marmorated Stink Bug (Hemiptera: Pentatomidae) Alters Blueberry Fruit Chemistry and Preference by Conspecifics. Environ. Entomol. 2016, 45, 1227-1234. [CrossRef]

10. Schumm, Z.R.; Alston, D.G.; Spears, L.R.; Manlove, K. Impact of Brown Marmorated Stink Bug (Hemiptera: Pentatomidae) Feeding on Tart Cherry (Rosales: Rosaceae) Quality and Yield in Utah. J. Econ. Entomol. 2020, 113, 2328-2334. [CrossRef] [PubMed] 
11. Mensah-Bonsu, M.; Dingha, B.N.; Jackai, L.E.N.; Adjei-Fremah, S.; Worku, M. Evaluation of preference of brown marmorated stink bug, Halyomorpha halys (Stål) for different colour bell peppers and the role of plant protein. Arthropod-Plant Interact. 2020, 14, 363-372. [CrossRef]

12. Heath, J.J.; Cipollini, D.F.; Stireman Iii, J.O. The role of carotenoids and their derivatives in mediating interactions between insects and their environment. Arthropod-Plant Interact. 2013, 7, 1-20. [CrossRef]

13. Zobel, E.S.; Hooks, C.R.R.; Dively, G.P. Seasonal Abundance, Host Suitability, and Feeding Injury of the Brown Marmorated Stink Bug, Halyomorpha halys (Heteroptera: Penatomidae), in Selected Vegetables. J. Econ. Entomol. 2016, 109, 1289-1302. [CrossRef] [PubMed]

14. Rice, K.B.; Bergh, C.J.; Bergmann, E.J.; Biddinger, D.J.; Dieckhoff, C.; Dively, G.; Fraser, H.; Gariepy, T.; Hamilton, G.; Haye, T.; et al. Biology, Ecology, and Management of Brown Marmorated Stink Bug (Hemiptera: Pentatomidae). J. Integr. Pest Manag. 2014, 5, A1-A13. [CrossRef]

15. Rokaya, P.; Baral, D.; Gautam, D.M.; Shrestha, A.; Paudyal, K. Effect of Postharvest Treatments on Quality and Shelf Life of Mandarin (Citrus reticulata Blanco). Am. J. Plant Sci. 2016, 7, 1098-1105. [CrossRef]

16. Samira, A.; Woldetsadik, K.; Workneh, T.S. Postharvest quality and shelf life of some hot pepper varieties. J. Food Sci. Technol. 2013, 50, 842-855. [CrossRef]

17. Hameed, R.; Malik, A.; Khan, A.S.; Imran, M.; Umar, M.; Riaz, R. Evaluating the effect of different storage conditions on quality of green chillies (Capsicum annuum L.). Trop. Agric. Res. 2015, 24, 391-399. [CrossRef]

18. Lama, K.; Alkalai-Tuvia, S.; Chalupowicz, D.; Fallik, E. Extended Storage of Yellow Pepper Fruits at Suboptimal Temperatures May Alter Their Physical and Nutritional Quality. Agronomy 2020, 10, 1109. [CrossRef]

19. Wiman, N.; Parker, J.; Rodriguez-Saona, C.; Walton, V. Characterizing Damage of Brown Marmorated Stink Bug (Hemiptera: Pentatomidae) in Blueberries. J. Econ. Entomol. 2015, 108, 1156-1163. [CrossRef]

20. Rehman, F.; Khan, F.A.; Badruddin, S.M.A. Role of Phenolics in Plant Defense Against Insect Herbivory. In Chemistry of Phytopotentials: Health, Energy and Environmental Perspectives; Khemani, L.D., Srivastava, M.M., Srivastava, S., Eds.; Springer: Berlin/Heidelberg, Germany, 2012; pp. 309-313.

21. Li, B.; Yang, M.; Shi, R.; Ye, M. Insecticidal Activity of Natural Capsaicinoids Against Several Agricultural Insects. Nat. Prod. Commun. 2019, 14. [CrossRef]

22. Li, Y.; Bai, P.; Wei, L.; Kang, R.; Chen, L.; Zhang, M.; Tan, E.K.; Liu, W. Capsaicin Functions as Drosophila Ovipositional Repellent and Causes Intestinal Dysplasia. Sci. Rep. 2020, 10, 9963. [CrossRef]

23. Soriano, I.R.; Asenstorfer, R.E.; Schmidt, O.; Riley, I.T. Inducible Flavone in Oats (Avena sativa) Is a Novel Defense Against Plant-Parasitic Nematodes. Phytopathology 2004, 94, 1207-1214. [CrossRef] [PubMed]

24. Othman, Z.A.A.; Ahmed, Y.B.H.; Habila, M.A.; Ghafar, A.A. Determination of Capsaicin and Dihydrocapsaicin in Capsicum Fruit Samples using High Performance Liquid Chromatography. Molecules 2011, 16, 8919-8929. [CrossRef] [PubMed]

25. Nagy, Z.; Daood, H.; Ambrózy, Z.; Helyes, L. Determination of Polyphenols, Capsaicinoids, and Vitamin C in New Hybrids of Chili Peppers. J. Anal. Methods Chem. 2015, 2015, 102125. [CrossRef]

26. Ministry of Agriculture, Forestry and Food. Integrated Production Guidelines 2021. Available online: https://www.gov.si/en/ state-authorities/ministries/ministry-of-agriculture-forestry-and-food/ (accessed on 22 October 2020).

27. Zamljen, T.; Jakopič, J.; Hudina, M.; Veberič, R.; Slatnar, A. Influence of intra and inter species variation in chilies (Capsicum spp.) on metabolite composition of three fruit segments. Sci. Rep. 2021, 11, 4932. [CrossRef] [PubMed]

28. Singleton, V.L.; Orthofer, R.; Lamuela-Raventós, R.M. [14] Analysis of total phenols and other oxidation substrates and antioxidants by means of folin-ciocalteu reagent. In Methods in Enzymology; Academic Press: Cambridge, MA, USA, 1999; Volume 299, pp. 152-178.

29. Medic, A.; Jakopic, J.; Hudina, M.; Solar, A.; Veberic, R. Identification and quantification of the major phenolic constituents in Juglans regia L. peeled kernels and pellicles, using HPLC-MS/MS. Food Chem. 2021, 352, 129404. [CrossRef]

30. Mikulic-Petkovsek, M.; Schmitzer, V.; Jakopic, J.; Cunja, V.; Veberic, R.; Munda, A.; Stampar, F. Phenolic compounds as defence response of pepper fruits to Colletotrichum coccodes. Physiol. Mol. Plant Pathol. 2013, 84, 138-145. [CrossRef]

31. Sagun, S.; Collins, E.; Martin, C.; Nolan, E.J.; Horzempa, J. Alarm Odor Compounds of the Brown Marmorated Stink Bug Exhibit Antibacterial Activity. J. Pharmacogn. Nat. Prod. 2016, 2, 119. [CrossRef]

32. Esquivel, J.F. Stink bug rostrum length vs. stylet penetration potential. Entomol. Exp. Appl. 2019, 167, 323-329. [CrossRef]

33. Kissinger, M.; Tuvia-Alkalai, S.; Shalom, Y.; Fallik, E.; Elkind, Y.; Jenks, M.; Goodwin, M. Characterization of Physiological and Biochemical Factors Associated with Postharvest Water Loss in Ripe Pepper Fruit during Storage. J. Am. Soc. Hortic. Sci. 2005, 130, 735-741. [CrossRef]

34. Tano, K.; Kamenan, A.; Arul, J. Respiration and transpiration characteristics of selected fresh fruits and vegetables. Agron. Afr. 2009, 17, 103-115. [CrossRef]

35. Morkunas, I.; Ratajczak, L. The role of sugar signaling in plant defense responses against fungal pathogens. Acta Physiol. Plant. 2014, 36, 1607-1619. [CrossRef]

36. Wind, J.; Smeekens, S.; Hanson, J. Sucrose: Metabolite and signaling molecule. Phytochemistry 2010, 71, 1610-1614. [CrossRef] [PubMed] 
37. Pereira-Dias, L.; Vilanova, S.; Fita, A.; Prohens, J.; Rodríguez-Burruezo, A. Genetic diversity, population structure, and relationships in a collection of pepper (Capsicum spp.) landraces from the Spanish centre of diversity revealed by genotyping-bysequencing (GBS). Hortic. Res. 2019, 6, 54. [CrossRef]

38. Marchiosi, R.; dos Santos, W.D.; Constantin, R.P.; de Lima, R.B.; Soares, A.R.; Finger-Teixeira, A.; Mota, T.R.; de Oliveira, D.M.; Foletto-Felipe, M.d.P.; Abrahão, J. Biosynthesis and metabolic actions of simple phenolic acids in plants. Phytochem. Rev. 2020, 19, 865-906. [CrossRef]

39. Antoniali, S.; Leal, P.A.M.; Magalhães, A.M.d.; Fuziki, R.T.; Sanches, J. Physico-chemical characterization of 'Zarco HS' yellow bell pepper for different ripeness stages. Sci. Agric. 2007, 64, 19-22. [CrossRef]

40. Araujo, W.L.; Nunes-Nesi, A.; Nikoloski, Z.; Sweetlove, L.J.; Fernie, A.R. Metabolic control and regulation of the tricarboxylic acid cycle in photosynthetic and heterotrophic plant tissues. Plant Cell Environ. 2012, 35, 1-21. [CrossRef] [PubMed]

41. Zushi, K.; Matsuzoe, N. Postharvest Changes in Sugar, Organic Acid, Glutamic Acid and Antioxidant Contents in Tomato Fruit Grown under Salinity Stress. Environ. Control Biol. 2006, 44, 111-117. [CrossRef]

42. Leiss, K.A.; Maltese, F.; Choi, Y.H.; Verpoorte, R.; Klinkhamer, P.G.L. Identification of chlorogenic acid as a resistance factor for thrips in chrysanthemum. Plant Physiol. 2009, 150, 1567-1575. [CrossRef]

43. Mierziak, J.; Kostyn, K.; Kulma, A. Flavonoids as important molecules of plant interactions with the environment. Molecules 2014, 19, 16240-16265. [CrossRef]

44. War, A.R.; Paulraj, M.G.; Ahmad, T.; Buhroo, A.A.; Hussain, B.; Ignacimuthu, S.; Sharma, H.C. Mechanisms of plant defense against insect herbivores. Plant Signal. Behav. 2012, 7, 1306-1320. [CrossRef]

45. Yactayo-Chang, J.P.; Tang, H.V.; Mendoza, J.; Christensen, S.A.; Block, A.K. Plant Defense Chemicals against Insect Pests. Agronomy 2020, 10, 1156. [CrossRef]

46. Reyes-Escogido, M.D.L.; Gonzalez-Mondragon, E.G.; Vazquez-Tzompantzi, E. Chemical and pharmacological aspects of capsaicin. Molecules 2011, 16, 1253-1270. [CrossRef] [PubMed]

47. Aley, J.P.; Adams, N.J.; Ladyman, R.J.; Fraser, D.L. The efficacy of capsaicin as an equine repellent for chewing wood. J. Vet. Behav. 2015, 10, 243-247. [CrossRef]

48. Cowles, R.S.; Keller, J.E.; Miller, J.R. Pungent spices, ground red pepper, and synthetic capsaicin as onion fly ovipositional deterrents. J. Chem. Ecol. 1989, 15, 719-730. [CrossRef] [PubMed]

49. Olszewska, J.; Tęgowska, E. Opposite effect of capsaicin and capsazepine on behavioral thermoregulation in insects. J. Comp. Physiol. A 2011, 197, 1021-1026. [CrossRef] [PubMed]

50. Maliszewska, J.; Marcinkowska, S.; Nowakowska, A.; Kletkiewicz, H.; Rogalska, J. Altered heat nociception in cockroach Periplaneta americana L. exposed to capsaicin. PLoS ONE 2018, 13, e0194109. [CrossRef] 